\title{
Transitional Cell Carcinoma of the Bladder in Pediatric Patients: Where Do We Stand?
}

\section{Carcinoma de células transicionales de vejiga en pacientes pediatricos: ¿Dónde nos encontramos?}

\author{
Jaime Perez ${ }^{1,2}$ Julián Chavarriaga ${ }^{1}$ Paula Peña ${ }^{1}$ Gustavo Ramos ${ }^{1,4}$ Lynda Torres $^{1}$ Alejandra Bravo ${ }^{2}$ \\ Paola Orrego ${ }^{1}$ Nicolás Fernandez ${ }^{1,2,3}$
}

${ }^{1}$ Division of Urology, Hospital Universitario San Ignacio, Pontificia
Universidad Javeriana, Bogotá, Colombia
2 Department of Urology, Fundación Santa Fe de Bogotá, Colombia
${ }^{3}$ Division of Urology, Hospital for Sick Children (SickKids), University
of Toronto, Canada
${ }^{4}$ Division of Urology, Instituto Nacional de Cancerología, Bogotá, Colombia

Address for correspondence Julian Chavarriaga, MD, División de Urología, Hospital Universitario San Ignacio, Pontificia Universidad Javeriana, Carrera 7, No. 40-62, Bogotá, Colombia (e-mail: chavarriagaj@javeriana.edu.co).

Urol Colomb 2020;29:91-95.

\begin{abstract}
Keywords

- transitional cell carcinoma

- pediatrics

- hematuria

- neoplasm

- urinary bladder

Introduction Transitional cell carcinoma of the bladder (TCCB) is uncommon in the pediatric population, and its etiology, natural history and epigenetics remain poorly understood. We aim to describe six cases of TCCB in pediatric patients and discuss the state of the art in the management and follow-up of the patients with this uncommon early presentation.

Methods The clinicopathological data of 6 patients with TCCB who underwent transurethral resection of bladder tumor (TURBT) were obtained from our institutional database. The patient data were collected retrospectively. A review of the literature was performed, and the most relevant and trending data were analyzed.

Results A total of 6 patients (4 female, 2 male) were treated at our institution between 2004 and 2019. The mean age of the sample was 12 years, and the presenting symptoms were macroscopic hematuria (3 cases), suprapubic pain (2 cases), and 1 case was an incidental finding during pelvic ultrasonography. The long-term follow-up (median follow-up of 61 months) did not reveal recurrence.

Conclusion Transitional cell carcinoma of the bladder rarely presents in the pediatric population. Genetic and epigenetic anomalies have been proposed as causes, as well as carcinogenic exposure. The reported cases tend to have a good prognosis, and most are non-invasive at the diagnosis. Follow-up protocols are still lacking, as well as molecular insights on tumor development and prognostic markers.
\end{abstract}

received

September 1, 2019

accepted

November 4, 2019
DOI https://doi.org/

$10.1055 / \mathrm{s}-0039-3402486$.

ISSN 0120-789X.

e ISSN 2027-0119.
Copyright ( 2020 , Sociedad Colombiana License terms de Urología. Publicado por Thieme Revinter Publicações Ltda., Rio de Janeiro, Brazil. Todos los derechos reservados. 


\begin{abstract}
Resumen
Palabras clave

- células de transición carcinoma

- pediatría

- hematuria

- neoplasia

- vejiga urinaria

Introducción Carcinoma de células transicionales de vejiga (CCTV) es una patología rara en la población pediátrica, su etiología, historia natural y epigenetica son pobremente entendidos. El objetivo de este articulo es describir 6 casos de CCTV en pacientes pediátricos, discutir el estado del arte en el manejo y seguimiento de los pacientes.

Métodos Los datos clinicopatologicos de 6 pacientes con CCTV sometidos a resección transuretral de tumor vesical (RTU-TV) se analizaron de nuestra base de datos institucional. Los datos fueron recolectados y analizados de manera retrospectiva. Se realizo una revisión de la literatura y solo los artículos mas relevantes fueron analizados. Resultados Un total de 6 pacientes (4 mujeres, 2 hombres) fueron tratados en nuestra institución entre el 2004 y el 2019. La media de edad fue 12 años y los síntomas mas frecuentes fueron hematuria macroscópica ( 3 casos), dolor suprapúbico ( 2 casos) y en un caso fue un hallazgo incidental durante una ultrasonografía pélvica. El seguimiento a largo plazo (mediana de seguimiento de 61 meses) no mostro recurrencia en ningún paciente.

Conclusión CCTV se presenta infrecuentemente en la población pediátrica, Anomalías genéticas y epigeneticas han sido propuestas como causas predisponentes al igual que la exposición a carcinogénicos. Los casos reportados tienden a tener un buen pronostico y la gran mayoría son no musculo invasivos al momento del diagnostico. Protocolos de seguimiento no están claramente definidos igual que vías moleculares en la tumorogenésis y marcadores pronósticos.
\end{abstract}

\section{Introduction}

Bladder cancer is the third most common cancer in the general population, with an increasing incidence over the past few years. ${ }^{1,2}$ Its peak of incidence is at the sixth decade of life. At the time of diagnosis, $75 \%$ of the tumors are noninvasive, but they tend to recur in up to $70 \%$ of the cases, and $20 \%$ progress to become muscle-invasive during follow-up. It is unusual to diagnose patients with urothelial bladder cancer in the first and second decades of life. ${ }^{1}$

Reports have shown a prevalence of $1.35 \%$ to $1.6 \%$ of urothelial carcinomas in patients younger than 45 years and of $0.03 \%$ in those younger than 19 years. ${ }^{1,2}$ Transitional cell carcinoma of the bladder (TCCB) in pediatric patients is typically of mesodermal origin, with a male predominance (3:1), a 39 white race, fold risk, usually with a favorable prognosis and a tendency not to recur compared with adult TCCB., ${ }^{1,2}$ The reported overall survival (OS) at 5 years is of $95 \%$ in the pediatric population. ${ }^{3}$

Because TCCB is rare in the pediatric population, most studies have been small case series, and consensus is still lacking regarding protocols for diagnosis, treatment and follow-up. The risk factors and etiology are poorly understood to date. ${ }^{4-6}$

The present six-case series aims to expand the number of cases of TCCB reported with a long-term follow up and discuss the current state of the art in the management and follow-up of these patients.

\section{Methods}

After obtaining approval from the Institutional Review Board (under number: 135-2019), and with the informed consent forms fully signed, patient data were collected retrospectively from our database. Patient anonymity was guaranteed. The clinical data of 6 patients with TCCB who underwent transurethral resection of bladder tumor (TURBT) were obtained between 2004 and 2019. In total, 6 patients, 4 female and 2 male, were diagnosed with TCCB at 15 years of age or younger. We reviewed patient data for demographics, medical history, extension studies, ultrasound (US) images, histologic features, tumor grade (2016 World Health Organization) classification of tumors of the urinary system, and the pathologic stage using the 2017 American Joint Committee on Cancer (AJCC) staging system, 8 th edition. ${ }^{7}$ We also reviewed the patients' records to collect data on follow-up visits, including endoscopic evaluations of the lower urinary tract (LUT), and US images to determine recurrence-free survival (RFS) and OS.

\section{Results}

During the study period, 6 patients with a median age of $12.1 \pm 2.2$ years were identified. The median follow up of was 61 months, and none of the patients had recurrence. In total, 3 presented with hematuria, 2, with abdominal pain, and 1 was an incidental finding during an abdominal US. None of the patients presented involvement of the lamina propria (stage Ta: non-invasive papillary carcinoma). Three patients were diagnosed with low-grade transitional cell carcinoma (LGTCC), microscopic evaluation is depicted in - Fig. 1, one with Urothelial Proliferation of Uncertain Malignant Potential (UPUMP), one patient with Papillary urothelial neoplasm of low malignant potential (PUNLMP), - Fig. 2 shows US images, cystoscopic and microscopic evaluation. Another 

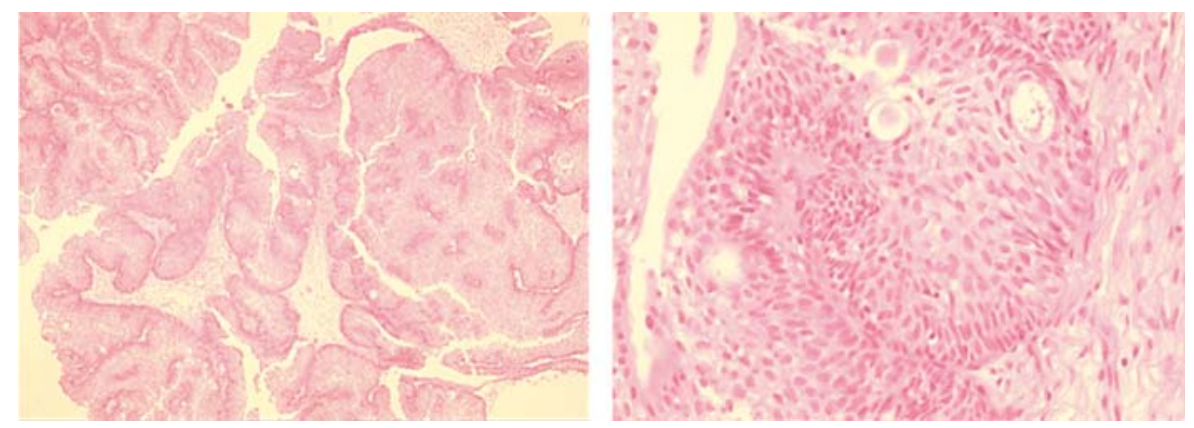

Fig. 1 Papillary transitional cell carcinoma of the bladder. Papillae lined by urothelium-like cells and nests of epithelial cells, pale granular cytoplasm, and large nucleoli.

with urothelial papilloma that despite being a benign neoplasm of the bladder and the recommendation to avoid labeling these patients as having cancer, we decided to reported it given that its clinical presentation was the same as the other patients. - Table 1 summarizes the clinical and demographic characteristics of the population.

The RFS was of $100 \%$ at a median follow-up of 61 months; 1 patient was followed up for 120 months. The OS was of $100 \%$; given the benign nature of this disease in children, our results are similar to those of previously-reported series of TCCB.
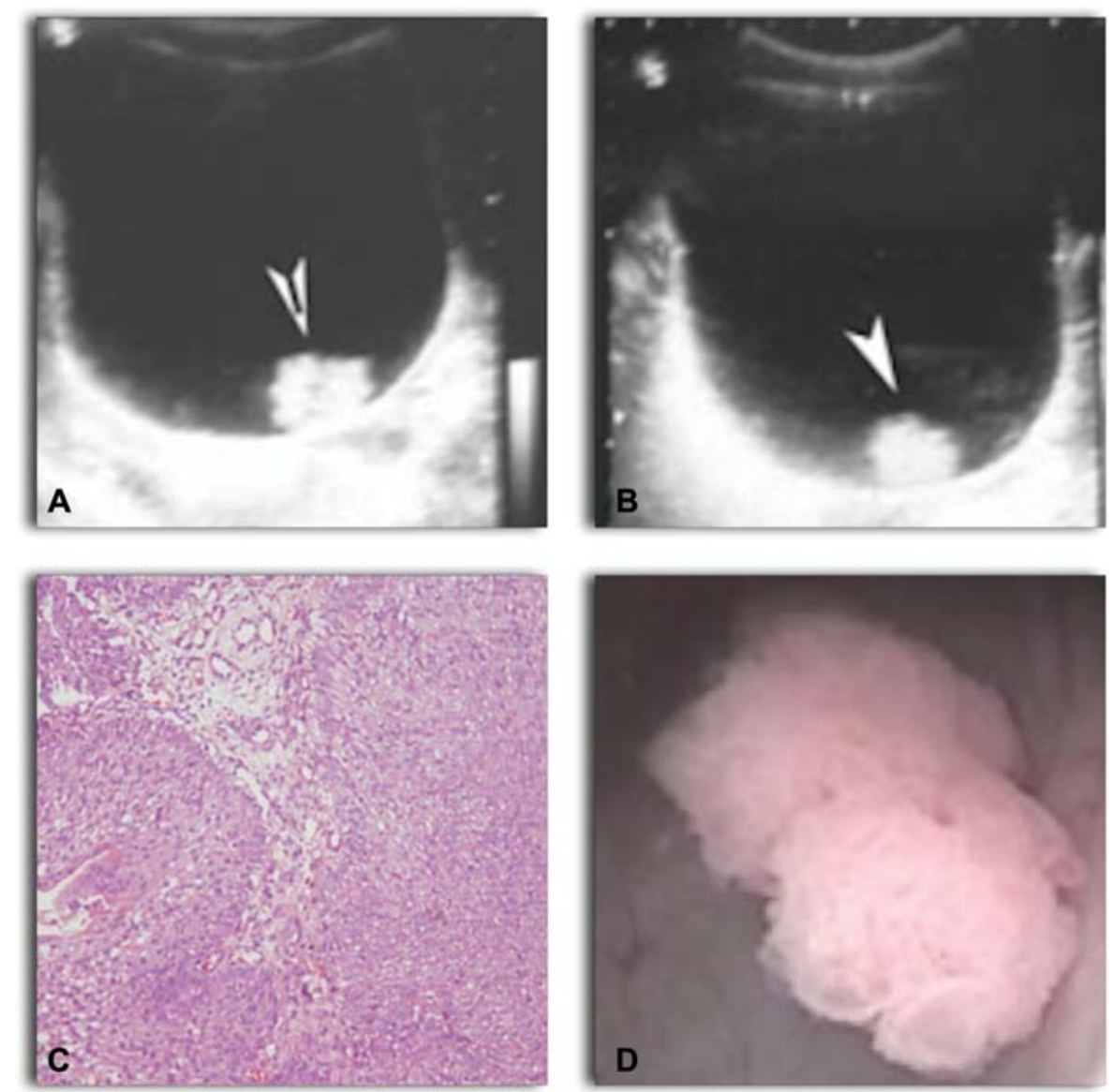

Fig. 2 (A and B) Ultrasound revealing an intravesical lesion with nodular, regular borders dependent of the left posterior wall. (C) 10X microscopic evaluation showing papillary urothelial neoplasm of low malignant potential with arrangement of cells within papillae with minimal architectural abnormalities and minimal nuclear atypia. Cystoscopy revealing a papillary, pedunculated 1-cm lesion at the left lateral wall of the bladder. 
Table 1 Clinical and demographic data of pediatric patients with transitional cell carcinoma of the bladder

\begin{tabular}{|l|l|l|l|l|l|l|l|l|l|}
\hline Patient & $\begin{array}{l}\text { Age } \\
\text { (years) }\end{array}$ & Gender & Symptom & Diagnosis & Location & Pathology & $\begin{array}{l}\text { Stage } \\
\text { (pT) }\end{array}$ & Recurrence & $\begin{array}{l}\text { Follow-up } \\
\text { (months) }\end{array}$ \\
\hline 1 & 11 & F & $\begin{array}{l}\text { Suprapubic } \\
\text { pain }\end{array}$ & US & $\begin{array}{l}\text { Left posterior } \\
\text { wall }\end{array}$ & LG, TCC & Ta & No & 120 \\
\hline 2 & 13 & F & $\begin{array}{l}\text { Right iliac } \\
\text { fossa pain }\end{array}$ & US & $\begin{array}{l}\text { Right posterior } \\
\text { wall }\end{array}$ & LGTCC & Ta & No & 96 \\
\hline 3 & 14 & M & Hematuria & US & Anterior wall & PUNLMP & Ta & No & 52 \\
\hline 4 & 11 & F & $\begin{array}{l}\text { None } \\
\text { (incidental } \\
\text { finding) }\end{array}$ & US & Left lateral wall & LGTCC & Ta & No & 6 \\
\hline 5 & 9 & M & Hematuria & US & Left lateral wall & $\begin{array}{l}\text { Urothelial } \\
\text { papilloma }\end{array}$ & Ta & No & 36 \\
\hline 6 & 15 & F & Hematuria & US & Left lateral wall & UPUMP & Ta & No & 56 \\
\hline
\end{tabular}

Abbreviations: F, female; LGTCC, low-grade transitional cell carcinoma; M, male; PT, Pathological Stage; PUNLMP, papillary urothelial neoplasm of low malignant potential; TCC, transitional cell carcinoma; UPUMP, urothelial proliferation of uncertain malignant potential; Ta, non-invasive papillary carcinoma; US, ultrasound.

Occupational and environmental factors are not well described in pediatric patients, given that it is unusual that they are exposed to them. Among those described, there are aniline dyes, aromatic amines, radiation, cyclophosphamide, chronic bladder irritation, and Schistosoma haematobium infection. ${ }^{10}$ The present long-term follow-up of these 6 cases of patients younger than 15 years adds to the current literature more insight about the natural history of TCCB and about how this tumor has a very different biological behavior in children compared with adults. ${ }^{11}$

The largest series to date was reported by Stanton et $\mathrm{al}^{13}$, with 59 patients younger than 30 years. They reported a male to female ratio of 1.8:1. The most common symptom was gross hematuria in 31 patients, followed by abdominal pain in 8 patients. Considering this heterogeneous symptomatology and the difficulty of the US being highly sensitive for these conditions, concern should be raised for clinicians evaluating the pediatric population, as TCCB might be a challenging condition to diagnose. Still regarding the study by Stanton et $\mathrm{al}^{13}$ at the diagnosis, 49 cases were of non-invasive carcinomas, and 10 were invasive (beyond the lamina propia). The follow up was available for 41 patients, with a mean time of 77 months. Of the noninvasive cases of TBCC, only 1 progressed, and the patient died of the disease, and 10 patients had local tumor recurrence. Of the 10 cases of invasive TBCC, 3 died of the disease, and 5 were alive with metastases. ${ }^{12}$ The present series, with a median follow-up of $62 \pm 46$ months and no invasive tumors at diagnosis, has shown better OS and RFS. To date, no molecular predictive markers have been described.

The second largest series was the study by Saltsman et al, who reported 34 patients with TBCCyounger than 25 years. ${ }^{12}$ At presentation, $76 \%$ of the patients complained of hematuria. In total, 39 cases were non-invasive, and 3 cases were invasive. ${ }^{12}$ The present series reports patients younger than 15 years of age at diagnosis, and this might explain the possible better prognosis compared with the 2 aforemen- tioned series, in which only 3 patients (in each series) were younger than 15 years. ${ }^{12,13}$

There is lacking information about clinical practice guidelines and clinical consensus for the surveillance and follow-up of TCCB in pediatric patients. Stanton et al and Saltsman et al. ${ }^{12,13}$ performed a median number of 5 cystoscopies per patient as part of their follow-up protocol. The interval between cystoscopies varied significantly, but they were generally performed every 6 months for the first year, and every 12 months thereafter. ${ }^{12,13} \mathrm{Kim}$ et $\mathrm{al}^{5}$ followed their 21 pediatric patients with TCCB with US and computed tomography (CT) scans without cystoscopy, and all patients were recurrence-free at 89 months. Urine cytology is a little invasive method with high sensitivity and specificity in cases of high-grade (HG) TBCC; however the sensitivity decreases to $6 \%$ to $38 \%$ in low-grade (LG) tumors in adult patients. Since most cases of TCCB in young patients are well-differentiated, urine cytology might not the best tool, and has not been recommended for diagnosis or follow-up. ${ }^{2}$ Our recommendation is to follow up the patients with US and cystoscopy every 6 months for the first 2 years, and with US only every 12 months thereafter. If there is any suspicion of recurrence on the US images, cystoscopy must be performed.

Genetic predisposition plays a key role in understanding TCCB in pediatric patients, and the disease should be interpreted as a different entity compared with adult TCCB. It has a unique tumor biology not yet fully understood. ${ }^{8,14,15}$ Some authors have suggested that mutations in fibroblast growth factor receptor 3 (FGFR3), tumor protein p53 (TP53) and deletions of chromosome 9 are frequent in adults. ${ }^{15-18}$ Williamson et $\mathrm{al}^{15}$ and Wild et $\mathrm{al}^{16}$ assessed the patients in their studies with TCCB with UroVysion (Abbott Laboratories, Abbott Park, IL, US) fluorescent in situ hybridization (FISH), showing that mutations of the FGFR3 and PT53 in patients younger than 19 years are rare or absent, supporting the hypothesis that TCCB has different molecular pathways when compared with transitional cell carcinogenesis. 
The role of microsatellite instability (MSI) and mismatch repair proteins (MRPs) remains controversial. In some studies, the authors did not find any MSI or MRP loss while in others a pronounced MSI was found in TCCB in pediatric patients. ${ }^{17,18}$ Mongiat-Artus et al $^{17}$ also assessed MSI in 17 young patients with TCCB using quasimonomorphic mononucleotide repeats (BAT-25, BAT-26, NR-21, NR-24, NR-27), and found only 1 patient with MSI, confirming that instability is rarely involved in pediatric TCCB.

Epigenetic events in TCCB have been described by Owen et al, ${ }^{19}$ who analyzed 76 cases of TCCB and proposed that some carcinogenic events occur at the epigenetic level rather than at the genetic level. The tumors in the youngest age group (younger than 19 years) had the lowest incidence of global hypermethylation, with a methyl index of $37.5 \%$ versus $62.5 \%$ (in patients aged between 20 and 45 years) and $50 \%$ (in patients aged 46 years or older). Younger patients had a significantly lower rate and concentration of methylation at the adenomatous polyposis coli (APC), Bcell lymphoma 2 Bcl2, 0-6-methylguanine-DNA-alkyltransferase (MGMT) and E-cadherin promoters than in the older groups; the concentration of APC and MGMT methylation increased with age. ${ }^{19}$ The epigenetic silencing of tumor necrosis factor receptor superfamily member 25 (TNFRSF25), which is a cellular receptor that regulates apoptosis when bound by a tumor necrosis factor (TNF) related ligand and correlates with tumor progression to advanced disease, has been a target of therapeutic interest, and it has been proposed that cell pretreatment with a histone deacetylase inhibitor, leading to increased histone acetylation and decreased TNFRSF25 hypermethylation, improved the apoptotic response to TNF. ${ }^{19}$ The loss of cyclin D2 plays a role in TCCB carcinogenesis and this molecule was methylated in all age groups in the study by Owen et al. ${ }^{19}$ Cyclin D2 is responsible for sequestrating the procell cycle kinases $\mathrm{Cy}$ clin-dependent kinase 4 CDK4 and Cyclin-dependent kinase 6 CDK6, preventing cell-cycle transition from G1 to the Sphase; therefore, loss of this cyclin attenuates the immune checkpoint, leading to uncontrolled proliferation. ${ }^{19}$

\section{Conclusion}

Transitional cell carcinoma of the bladder in pediatric patients remains a rare and poorly understood disease. The oncogenesis of this tumor in young patients has not yet been completely elucidated; however, there has been a huge progress in the understanding of the biologic, epigenetic and genetic mechanisms of this disease. Despite some large series that have been reported, there is still lack of consensus regarding the standard of care for these patients and followup protocols. We developed our own follow-up schedule based on our experience with large series. Given the rarity of this disease, every effort should be made to address these patients not only at the clinical level but also at the genetic, biologic and molecular levels.

Conflict of Interests

The authors have no conflict of interests to declare.

\section{References}

1 Javadpour N, Mostofi FK. Primary epithelial tumors of the bladder in the first two decades of life. J Urol 1969;101(05): 706-710

2 Lerena J, Krauel L, García-Aparicio L, Vallasciani S, Suñol M, Rodó J. Transitional cell carcinoma of the bladder in children and adolescents: six-case series and review of the literature. J Pediatr Urol 2010;6(05):481-485

3 Alanee S, Shukla AR. Bladder malignancies in children aged $<18$ years: results from the Surveillance, Epidemiology and End Results database. BJU Int 2010;106(04):557-560

4 Rifat UN, Hamadalla NY, Chiad Safi KC, Al Habash SS, Mohammed M, Hospital J. Urothelial bladder tumour in childhood: A report of two cases and a review. Arab J Urol 2015;13(02):116-121. Doi: 10.1016/j.aju.2014.11.002 [Internet]

5 Kim SC, Park S, Song SH, Kim KS, Park S. Clinicopathological Characteristics of Urinary Bladder Tumors in Korean Patients 20 Years or Younger. J Korean Med Sci 2018;33(40):e242

6 Dowling CR, Reddihough D, Smith P, Webb N, McNeill R, Clouston D. Transitional cell carcinoma in the paediatric population: be aware of unusual aetiologies. J Paediatr Child Health 2007; 43(11):773-775

7 Humphrey PA, Moch H, Cubilla AL, Ulbright TM, Reuter VE. The 2016 WHO Classification of Tumours of the Urinary System and Male Genital Organs-Part B: Prostate and Bladder Tumours. Eur Urol 2016; 70(01):106-119. Doi: 10.1016/j.eururo.2016.02.028 [Internet]

8 Wang L, Fu D, Qiu Y, et al. Genome-wide screening and identification of long noncoding RNAs and their interaction with protein coding RNAs in bladder urothelial cell carcinoma. Cancer Lett 2014; 349(01):77-86. Doi: 10.1016/j.canlet.2014.03.033 [Internet]

9 Uçar M, Demirkaya M, Aytaç Vuruşkan B, Balkan E, Kılıç N, Kılıç N. Urothelial Carcinoma of the Bladder in Pediatric Patient: Four Case Series and Review of the Literature. Balkan Med J 2018;35(03): 268-271

10 Bujons A, Caffaratti J, Garat JM, Villavicencio H. Long-term follow-up of transitional cell carcinoma of the bladder in childhood. J Pediatr Urol 2014;10(01):167-170

11 Pérez Niño J, Malo Rodríguez G, Llinás Lemus E. Comportamiento de las neoplasias uroteliales de vejiga en adolescentes. Urol Colomb. 2009;18(02):7

12 Saltsman JA, Malek MM, Reuter VE, Hammond WJ, Danzer E, Herr HW, LaQuaglia MP. Urothelial neoplasms in pediatric and young adult patients: A large single-center series. J Pediatr Surg 2018;53 (02):306-309

13 Stanton ML, Xiao L, Czerniak BA, Guo CC. Urothelial tumors of the urinary bladder in young patients: a clinicopathologic study of 59 cases. Arch Pathol Lab Med 2013;137(10):1337-1341

14 Castillo-martin M, Collazo A, Gladoun N. H-RAS mutation is a key molecular feature of pediatric urothelial bladder cancer. A detailed report of three cases. J Pediatr Urol 2015(March):1-7. Doi: 10.1016/ j.jpurol.2015.08.020 [Internet]

15 Williamson SR, Wang M, Montironi R, et al. Molecular characteristics of urothelial neoplasms in children and young adults: a subset of tumors from young patients harbors chromosomal abnormalities but not FGFR3 or TP53 gene mutations. Mod Pathol 2014;27(11):1540-1548. Doi: 10.1038/modpathol.2014.48

16 Wild PJ, Giedl J, Stoehr R, et al. Genomic aberrations are rare in urothelial neoplasms of patients 19 years or younger. J Pathol 2007;211(01):18-25

17 Mongiat-Artus P, Miquel C, Van Der Aa M. Infrequent Microsatellite Instability in Urothelial Cell Carcinoma of the Bladder in Young Patients. Eur Urol 2006;49:685-690

18 Christensen M, Jensen MA, Wolf H, Orntoft TF. Pronounced microsatellite instability in transitional cell carcinomas from young patients with bladder cancer. Int J Cancer 1998;79(04):396-401

19 Owen HC, Giedl J, Wild PJ, et al. Low frequency of epigenetic events in urothelial tumors in young patients. J Urol 2010;184 (02):459-463. Doi: 10.1016/j.juro.2010.03.131 